\title{
DEFISIENSI BESI DAN ANEMIA PADA ANAK USIA BAWAH DUA TAHUN (6-23 BULAN) DI KABUPATEN ACEH BESAR
}

\author{
Aripin Ahmad, Siti Zulfah, Silvia Wagustina \\ Jurusan Gizi Politeknik Kesehatan Kemenkes Aceh \\ aripin_aceh@yahoo.com
}

\begin{abstract}
ABSTRAK
Anemia pada balita di Indonesia masih sangat tinggi, hasil Susenas (2001) menunjukkan rata-rata 47 persen balita menderita anemia dengan prevalensi terbesar pada usia $6-11$ bulan yaitu 64,8 persen. $\mathrm{Di}$ Aceh, Survei Word Vision Indonesia (2010) 67,8 persen anak balita menderita anemia, sementara data Riskesadas 2013 didapatkan anemia pada anak usia $12-59$ bulan 30,3 persen di kota dan 25,8 persen di pedesaan. Salah satu faktor yang sangat mempengaruhi anemia adalah status besi. Penelitian ini bertujuan untuk mengetahui status besi dan anemia pada anak baduta usia 6-23 bulan di Kabupaten Aceh Besar. Penelitian ini menggunakan desain cross-sectional survei dilaksanakan pada bulan Agustus 2011 pada tiga kecamatan, yaitu Kecamatan Lhoknga, Leupung dan Lhong Kabupaten Aceh Besar. Sampel penelitian adalah anak usia 6-23 bulan berjumlah 257 orang yang diambil dengan metode stratified random sampling. Data kadar Haemoglobin $(\mathrm{Hb})$ dikumpulkan dengan metode cyanmethaemoglobin dan serum Ferritin dengan metode ELISA oleh tenaga laboran terlatih di Laboratorium "P" Banda Aceh. Analisis hubungan antara kadar serrum Ferritin dengan Anemia digunakan uji chi-square pada derajat kepercayaan $95 \%$. Hasil penelitian didapatkan 46,7 persen sampel menderita anemia dan 36,2 persen menderita defisiensi besi. Setelah dilakukan analisis penentuan jenis anemia, didapatkan sampel dengan kadar $\mathrm{Hb}$ dan status besi normal sebesar 43,6 persen, anemia defisiensi besi 26,5 persen, defisiensi besi tidak anemia 9,7 persen, dan anemia tetapi status besi normal 20,2 persen. Anemia lebih banyak didapatkan pada anak baduta dengan status defisiensi besi, yaitu 73,1 persen dibandingkan anak non defisiensi 31,7 persen. Ada perbedaan yang signifikan antara defisiensi besi dengan anemia $(p=0,00)$ dan nilai Odd Ratio $(O R)=5,8$. Anemia anak baduta di Aceh merupakan "severe public health problem" dengan penyebab defisiensi zat besi. Untuk itu sangat diperlukan upaya peningkatan asupan zat besi dari makanan terutama MPASI, intervensi pemberian suplementasi besi untuk mencegah terjadinya anemia pada anak baduta.
\end{abstract}

Kata kunci: anemia, defisiensi besi, anak usia 6-23 bulan

\section{ABSTRACT \\ IRON DEFICIENCY AND ANEMIA AMONG UNDER-TWO-YEAR-OLD-CHILDREN (6-23 MONTHS) IN ACEH BESAR DISTRICT}

Anemia among under-five year children in Indonesia remained high. The Social Economic National Survey (Susenas) in 2001 showed that 47 perc ent under five children suffered anemia and 64.8 per cent of them were 6-11 months. Anemia in Aceh is also high, World Vision Indonesia Survey in 2010 obtained that 67.8 per cent under-five- year-old-children suffered from anemia. Riskesdas 2013 showed 30.3 per cent anemia was found at 12-59 month old in urban and 25.8 per cent in rural. One of the factors that influences anemia was iron status. This study aimed to determine iron status and anemia in children aged 6-23 months in Aceh Besar District. This study used a cross-sectional design that was conducted in August 2011 at three subdistricts in Aceh Besar, namely Lhoknga, Leupung and Lhong. A total of 257 children were taken as subjects with stratified random sampling method. Haemoglobin levels were collected by cyanmethaemoglobin method and serum ferritin was measured using ELISA method by trained staff at "P" Laboratory Banda Aceh. To analyse the relationship between ferritin serum levels and anemia, chisquare test was used at 95 per cent confidence level. The study showed that 46.7 per cent children aged 6 23 months suffered from anemia and 36.2 per cent was iron deficiency. After analyzing the type of anemia, it showed that 43.6 per cent children were normal, 26,5 per cent were iron deficiency anemia, 9.7 per cent were iron deficiency without anemia; and 20.2 per cent were anemia without iron deficiency. Anemia among children with iron deficiency was 73.1 per cent, and non iron deficiency children was 31.7 per cent. There was a significant different between iron deficiency and anemia in children aged 6-23 month $(p=0.00)$ with Odd Ratio (OR) 5.8. Anemia among children aged 6-23 month was a severe public health problem and iron deficiency is the main cause of anemia in Aceh Besar District. Therefore, it was important to improve iron intake from complementary feeding and iron supplement intervention for 6-23 month old children.

Keywords: anemia, iron deficiency, children aged 6-23 month 


\section{PENDAHULUAN}

$\mathrm{D}$ efisiensi besi merupakan masalah kekurangan gizi yang diderita lebih dari dua miliar orang di seluruh dunia. Anemia defisiensi besi sangat lazim terjadi di negara-negara berkembang tetapi juga masih menjadi masalah di negara maju. Kekurangan zat besi bukanlah satu-satunya penyebab anemia, tetapi kekurangan zat besi merupakan penyebab yang paling utama. ${ }^{1}$

Anemia di Indonesia sampai saat ini masih menjadi masalah gizi utama. Prevalensi anemia pada balita di Indonesia masih sangat tinggi, hasil Survei Kesehatan Rumah Tangga (SKRT) tahun 2001 menunjukkan prevalensi anemia defisiensi besi (ADB) pada bayi $0-6$ bulan 61,3 persen, bayi $6-12$ bulan 64,8 persen, dan anak balita 48,1 persen. ${ }^{2}$ Data terakhir Riset Kesehatan Dasar (Riskesdas) tahun 2013 menunjukkan anemia pada anak 12-59 bulan sebesar 28,1 persen. ${ }^{3}$ Angka ini tidak berbeda jauh dengan Riskesdas 2007 yang menemukan satu dari empat anak usia sekolah dasar menderita kekurangan besi. ${ }^{4}$

Prevalensi anemia di Provinsi Aceh juga sangat tinggi, berdasarkan hasil survei yang dilakukan oleh Word Vision Indonesia (2010) di empat wilayah dampingannya, yaitu Aceh Besar, Banda Aceh, Aceh Jaya dan Aceh Barat dengan melakukan pemeriksaan kadar haemoglobin dengan metode cyanmethemoglobin didapatkan prevalensi anemia pada balita sangat tinggi, yaitu 67,8 persen ${ }^{5}$ Hasil penelitian Ahmad, dkk. (2011) di Kecamatan Darul Imarah Aceh Besar pada anak usia 6-23 bulan dengan melakukan pemeriksaan haemoglobin didapatkan penderita anemia juga sangat tinggi, yaitu 78,3 persen. ${ }^{6}$

WHO mengklasifikasikan anemia menjadi 3 (tiga) macam berdasarkan penyebabnya, yaitu iron defisiensi, iron defisiensi anemia, dan anemia. Iron defisiensi adalah anemia yang disebabkan oleh defisiensi zat besi yang terjadi karena rendahnya cadangan zat besi dalam tubuh akibat dari kurangnya asupan zat besi dari makanan. Sedangkan Iron Defisiensi anemia adalah anemia yang disebabkan oleh kurangnya zat besi dan zat gizi lainnya seperti protein, vitamin dan mineral yang berperan dalam pembentukan haemoglobin $(\mathrm{Hb})$, sementara anemia saja disebabkan oleh kekurangan zat gizi selain zat besi, sehingga pemeriksaan haemoglobin $(\mathrm{Hb})$ saja belum menggambarkan apakah seorang mengalami defisiensi zat besi. ${ }^{7}$

International Anemia Consultative Group (INACG), ${ }^{8}$ menyatakan perlunya perubahan cara pandang tentang anemia, dimana defisiensi zat besi bukan lagi penyebab dominan dari anemia. Hal ini dapat dilihat dari data di negara berkembang (Afrika dan Asia) bahwa prevalensi anemia hanya sekitar 50 persen disebabkan oleh defisiensi besi selebihnya karena defisiensi zat gizi mikro lain, yaitu vitamin $A$, seng $(Z n)$ dan asam folat serta adanya infeksi malaria, cacing serta sebab lain.

Status gizi besi dalam tubuh dapat ditentukan secara biokimia dengan menggunakan berbagai parameter antara lain kadar haemoglobin darah, kadar haematokrit $(\mathrm{HCT})$, ferritin dalam serum. Masing-masing parameter dapat menggambarkan perubahan komposisi zat besi dalam tubuh. International Anaemia Consultattive Group(INACG) ${ }^{9}$ ada tiga tahapan terjadinya defisiensi besi dalam tubuh, yaitu perubahan besi pada simpanan (storage), perubahan besi pada saat transportasi dan pada tahapan fungsi metabolik. Pertama defisiensi besi terjadi ketika tubuh hampir atau tidak mempunyai lagi simpanan besi (iron depletion), yaitu jumlah zat besi yang sedang tidak digunakan untuk keperluan jaringan tubuh seperti otot, otak dan darah, walaupun pada kondisi ini kadar $\mathrm{Hb}$ dalam kondisi normal. Pada tahapan ini belum ada gejala gangguan/efek dalam tubuh indikator tidak adanya simpanan zat besi adalah menurunnya serum ferritin (SF) atau meningkatnya total iron binding capacity $(T I B C)$. Kedua adalah terjadi kekurangan zat besi lebih lanjut dari tahapan pertama yang disebut iron deficiency erythropoesis (IDE) atau dikenal juga dengan istilah functional iron deficiency. Tahapan kedua ini terjadi karena gangguan transportasi zat besi dari pool (simpanan) ke jaringan meskipun simpanan yang dimiliki masih mencukupi. Kondisi ini terjadi akibat imflamasi atau kekurangan vitamin, yang ditandai dengan penurunan suplai besi ke sum-sum tulang sehingga produksi sel darah merah menurun. Indikator pada tahapan ini adalah menurunnya serum besi, menurunnya transferin saturation/TIBC, tingginya free erythrocyte protophorphyrin dan tinginya serum transferrin receptor $(\mathrm{STfR})^{7}$. Ketiga adalah tahapan paling parah dari defisiensi besi yang 
ditunjukkan oleh menurunnya konsentrasi haemoglobin dan hematokrit. Anemia Defisiensi besi terjadi karena tidak sempurnanya pembentukan haemoglobin yang menyebabkan ukuran sel darah merah lebih kecil (microcytic) dan mengandung lebih sedikit haemoglobin (hypocromic) $^{10}$. Ferritin adalah suatu protein penyimpanan besi yang merupakan penduga yang relatif lebih teliti mengenai cadangan besi. Serum ferritin merupakan petunjuk kadar cadangan besi dalam tubuh. Pemeriksaan kadar serum ferritin dikerjakan untuk menentukan diagnosis defisiensi besi, karena kadar serum ferritin sebagai indikator paling dini menurun bila cadangan besi menurun ${ }^{10}$. Indikator paling baik untuk menentukan defisit besi adalah Haemoglobin $(\mathrm{Hb})$ dan Serum Ferritin (SF), namun untuk daerah yang sering terjadi infeksi disarankan menambah indikator serum transferin receptor (STfR) karena ferritin sangat dipengaruhi oleh imflamasi akibat infeksi dan penyakit kronis ${ }^{7}$. Selama ini upaya penanggulangan anemia gizi masih difokuskan pada sasaran ibu hamil, sedangkan kelompok lainnya seperti bayi, anak balita belum ditangani secara menyeluruh. Defisiensi besi dan anemia defisiensi besi pada balita dapat menyebabkan gangguan perkembangan kognitif yang berdampak pada menurunnya perkembangan kecerdasan, yang dimulai dari bayi sampai dewasa, mempengaruhi sistim imunitas dan dapat meningkatkan angka kematian ${ }^{10}$.

Penelitian ini bertujuan untuk mengetahui prevalensi anemia dan anemia defisiensi besi (iron deficiency anemia) berdasarkan pemeriksaan kadar feritin dan hubungan kadar serum ferritin dengan anemia pada anak bawah dua tahun (6-23 bulan) di Kabupaten Aceh Besar. Hasil penelitian diharapkan dapat dijadikan dasar penentuan jenis intervensi dalam rangka penanggulangan masalah gizi di Aceh.

\section{METODE PENELITIAN}

Penelitian bersifat deskriptif analitik dengan desain crossectional study dilakukan di 3 (tiga) Kecamatan di Kabupaten Aceh Besar, yaitu Kecamatan Lhoknga, Leupung dan Lhong yang dilaksanakan pada bulan Agustus 2011. Populasi penelitian adalah seluruh anak usia
6-23 bulan berjumlah 613 anak. Hasil perhitungan besar sampel survei dengan rumus Slovin dan dikoreksi dengan desain effect jumlah sampel dikali 3 maka didapatkan besar sampel sebanyak 257 anak baduta. Pengambilan sampel dilakukan dengan metode stratified random sampling. Desa-desa di tiga kecamatan dijadikan sebagai strata, dari setiap desa diambil sampel secara random, jumlah sampel dari setiap desa ditetapkan secara proporsional berdasarkan jumlah populasi anak baduta.

Variabel penelitian yang dikumpulkan adalah status besi menggunakan parameter serum ferritin dengan metode Enzyme-Linked Immunoassay (ELISA) dengan batasan defisiensi besi bila Ferritin $<12 \mathrm{mg} / \mathrm{L}$ dan kadar Haemoglobin $(\mathrm{Hb})$ dengan metode Cyhianmethaemoglobin dengan batasan anemia bila Kadar $\mathrm{Hb}<11 \mathrm{~g} / \mathrm{dL}$. Instrumen yang digunakan untuk pengumpulan data berupa kuesioner terstruktur untuk karakteristik sampel dan formulir pencatatan hasil pemeriksaan serum ferritin dan kadar $\mathrm{Hb}$. Pengumpulan data dilakukan dengan tahapan 1). Enumerator mengunjungi sampel terpilih dan meminta persetujuan sebagai sampel dengan menandatangani form inform consent selanjutnya melakukan wawancara tetang karakteristik sampel 2). Pengambilan specimen darah 2,5 cc setiap sampel dilakukan di Puskesmas yang telah disiapkan tim 4 orang tenaga laboran dari Laboratorium "P" Banda Aceh 3). Pemeriksaan kadar serum ferritin dengan metode ELISA dan Kadar $\mathrm{Hb}$ dengan metode Cyanmethaemoglobin.

Analisis data dilakukan secara univariat dan bivariat, analisis univariat dilakukan untuk mengetahui distribusi frekuensi, rata-rata, standar deviasi, sedangkan analisis bivariat untuk mengetahui hubungan antara kadar serum ferritin dengan kadar $\mathrm{Hb}$ menggunakan uji statitik chi-square test mengunakan tingkat kepercayaan 95 persen $(\alpha=0,05)$. Penelitian ini telah mendapat kaji etik pelaksanaan penelitian dari Komisi Etik Penelitian Kesehatan Badan Penelitian dan Pengembangan Kesehatan (Badan Litbangkes) Kemenkes RI Jakarta dengan nomor Surat Persetujuan Etik (Ethical Approval) Nomor KE.01.07/EC/467/2011 Tanggal 29 Juli 2011. 
HASIL

Penelitian ini dilakukan pada 257 sampel anak bawah dua tahun (6-23 bulan) di tiga kecamatan, yaitu Lhoknga, Leupung dan Lhong Kabupaten Aceh Besar. Berdasarkan umur sampel didapatkan 24,9 persen berumur antara 6-11 bulan dan 75,1 persen berumur 12-23 bulan. Sedangkan menurut jenis kelamin 54,9 persen perempuan dan 45,1 persen laki-laki, sedangkan menurut urutan anak ke dalam keluarga sebagian besar sampel adalah anak pertama ( 89,9 persen).

\section{Kadar Hb dan Serum Ferritin}

Hasil penelitian didapatkan rata-rata kadar Haemoglobin $(\mathrm{Hb}) 10,9 \pm 1,14 \mathrm{~g} / \mathrm{dL}$ dan rata-rata kadar serum ferritin $23,9 \pm 23,1 \mu \mathrm{g} / \mathrm{L}$. Untuk menentukan status anemia dan anemia defisiensi besi digunakan standart $\mathrm{WHO}^{7}$, yaitu dikatakan anemia bila kadar Haemoglobin untuk anak usia 6 bulan sampai 6 tahun adalah 11 $\mathrm{mg} / \mathrm{dL}$ dan defisiensi besi menggunakan parameter ferritin bila kadar serum ferritin $<12 \mu \mathrm{g} / \mathrm{L}$.

Berdasarkan hasil analisis data (Tabel 1) didapatkan 46,7 persen anak baduta mengalami anemia $(\mathrm{Hb}<11 \mathrm{~g} / \mathrm{dL})$ dan 36,2 persen mengalami defisiensi zat besi. Setelah dilakukan analisis kombinasi antara Haemoglobin dan kadar serum ferritin untuk penentuan jenis anemia didapat prevalensi anemia dengan defisiensi besi berbeda. Jumlah anak baduta yang mengalami anemia dan defisiensi besi atau Iron Deficency Anemia (IDA) adalah 26,5 persen, defisiensi besi saja tanpa anemia 9,7 persen, anemia dengan status besi normal adalah 20,2 persen.

Tabel 1

Distribusi Status Anemia dan Defisiensi Besi pada Anak Baduta 6-23 bulan di Kabupaten Aceh Besar ( $n=257)$

\begin{tabular}{lcc}
\hline Parameter Anemia & $\mathrm{n}$ & persen \\
\hline Kadar Hb & 120 & \\
$\quad$ - Anemia $(<11 \mathrm{~g} / \mathrm{dL})$ & 137 & 46,7 \\
$\quad$ - Normal $(\geq 1 \mathrm{~g} / \mathrm{dL})$ & & \\
\hline Serum Ferritin & 93 & 36,3 \\
$\quad$ - Defisiensi besi $(<12 \mu \mathrm{g} / \mathrm{L})$ & 164 & 63,8 \\
- Normal $((\geq 12 \mu \mathrm{g} / \mathrm{L})$ & & \\
\hline Kombinasi Hb dan Ferritin & 112 & 43,6 \\
- Normal & 68 & 26,5 \\
- Anemia dan Defisiensi besi & 25 & 9,7 \\
- Tidak anemia, Defisiensi besi & 52 & 20,2 \\
- Anemia, tidak defisiensi besi & & \\
\hline
\end{tabular}

Tabel 2

Hubungan Defisiensi Besi dengan Anemia pada Anak Baduta 6-23 di Kabupaten Aceh Besar

\begin{tabular}{|c|c|c|c|c|}
\hline \multirow{2}{*}{$\begin{array}{l}\text { Status Besi } \\
\text { (Serum ferritin) }\end{array}$} & \multicolumn{2}{|c|}{ Status $\mathrm{Hb}$} & \multirow{2}{*}{ Jumlah } & \multirow{2}{*}{$p$} \\
\hline & Anemia & Normal & & \\
\hline Defisiensi & $68(73,1)$ & $25(26,9)$ & $93(100,0)$ & $0,00(p<0,05)$ \\
\hline Normal & $52(31,7)$ & $112(68,3)$ & $164(100,0)$ & $\mathrm{OR}=5,8(3,3-10,2)$ \\
\hline
\end{tabular}

\section{Hubungan defisiensi besi dengan anemia pada anak baduta}

Hasil penelitian (Tabel 2) didapatkan proporsi anak baduta yang mengalami anemia
$(\mathrm{Hb}<11 \mathrm{mg} / \mathrm{L})$ lebih tinggi pada anak yang mengalami defisiensi besi (serum ferritin<12mg/L), yaitu 73,1 persen dibandingkan pada anak yang serum ferritinnya 
normal (serum ferritin $\geq 12 \mathrm{mg} / \mathrm{L}$ ), yaitu 31,7 persen. Hasil uji statistik menunjukkan ada hubungan yang signifikan antara defisiensi besi dengan anemia pada anak baduta $p=0,00$ $(p<0,05)$ dan nilai Odd Ratio $(O R)=5,8$. Artinya anak yang mengalami defisiensi besi 5,8 kali berisiko lebih besar untuk menderita anemia dibandingkan dengan anak yang tidak defisiensi besi.

\section{BAHASAN}

Hasil penelitian (Tabel 2) menunjukkan persentase anemia pada anak baduta di 3 kecamatan lokasi penelitian sangat tinggi $(46,3$ persen), demikian juga angka prevalensi defisiensi besi, yaitu 35,8 persen anak baduta mengalami defisiensi besi. Hasil ini menggambarkan anemia masih merupakan masalah kesehatan masyarakat dengan kategori berat di Aceh Besar. Anemia dianggap menjadi masalah kesehatan masyarakat bila prevalensinya diatas 5 persen, jika dibandingkan dengan ketentuan ini maka prevalensi anemia di 3 kecamatan lokasi penelitian khususnya termasuk kategori berat (severe public health problem) karena prevalensinya berada $>40$ persen. ${ }^{11}$

Hasil penelitian ini tidak jauh berbeda hasil Susenas tahun $2001^{2}$ rata-rata 47 persen balita anemia dengan prevalensi terbesar pada usia 6-11 bulan yaitu 64,8 persen. Demikian juga dengan hasil yang dilakukan di empat kabupaten/kota oleh World Vision Indonesia $(\mathrm{WVI})^{6}$ di Kabupaten Aceh Besar prevalensi anemia pada balita didapatkan sebesar 68,5 persen. Namun ada perbedaan sampel, pada survei WVI sampel yang diambil adalah balita 1-5 tahun, sedangkan pada penelitian ini anak baduta usia $6-23$ bulan. Artinya jika pada penelitian ini prevalensi anemia sedikit lebih rendah dari survei anemia 2010 dapat disebabkan oleh perbedaan sampel. Ada kecenderungan dari hasil penelitian ini semakin bertambah umur prevalensi anemia semakin tinggi dimana prevalensi anemia lebih tinggi pada umur 12-23 bulan (58,0 persen) dibandingkan usia 6-11 bulan hanya (40,6 persen).

Tingginya prevalensi anemia pada anak baduta juga ditunjukkan dari beberapa hasil penelitian, Hasil survei nasional di Filipina juga menunjukkan prevalensi anemia pada anak baduta juga sangat tinggi, yaitu 56 persen pada usia 6-11 bulan dan 41 persen pada usia 12-23 bulan $^{12}$. Di Indonesia pada tahun 2013 prevalensi anemia secara nasional lebih rendah dari hasil penelitian ini, yaitu 28,1 persen anak usia 12-59 bulan menderita anemia, prevalensi lebih tinggi di pedesaan 22,8 persen dibandingkan di perkotaan 20,6 persen ${ }^{3}$. Hasil penelitian lain oleh Olney, dkk. ${ }^{13}$ di Zanzibari pada anak 5-19 bulan juga didapatkan anemia 58,9 persen. Hasil penelitian Hassan, dkk ${ }^{14}$ di 8 camp pengungsian di Gaza, Syiria, Jordan dan Lebanon pada anak 6-35,9 bulan didapatkan rata-rata prevalensi anemia adalah 67 persen.

Penelitian ini juga memberikan gambaran masalah defisiensi besi pada anak baduta khususnya di wilayah penelitian sangat tinggi, dimana 36,2 persen anak baduta mengalami defisiensi besi (Ferritin<12mg/L). Keadaan ini memberikan indikasi bahwa defisiensi besi masih merupakan salah satu penyebab anemia, namun demikian tidak semua anemia disebabkan oleh defisiensi besi. Hasil analisis kombinasi $\mathrm{Hb}$ dan kadar feritin (Tabel 2) untuk penentuan jenis anemia, didapatkan anak baduta yang defisiensi besi (ferritin $<12 \mathrm{mg} / \mathrm{L}$ ) dan $\mathrm{Hb}$ juga rendah $(\mathrm{Hb}, 11 \mathrm{mg} / \mathrm{dL})$ adalah 26,5 persen, sementara 9,7 persen yang defisiensi besi tetapi $\mathrm{Hb}$ normal dan 9,7 persen yang hanya mengalami defisiensi besi tanpa anemia ( $\mathrm{Hb}$ normal). Kondisi ini menunjukkan pemeriksaan $\mathrm{Hb}$ saja belum menggambarkan apakah seorang mengalami defisiensi besi, dapat dilihat dari adanya perbedaan proporsi anak baduta yang mengalami anemia dengan defisiensi besi. Hasil penelitian ini hampir sama dengan penelitian Olney, dkk ${ }^{13}$ di Zanzibari pada anak 5-19 bulan juga didapatkan angka defisiensi besi yang tinggi, yaitu 77,0 persen, sedangkan 70,8 persen menderita defisiensi besi dan anemia.

Prevalensi anemia yang tinggi pada balita memberikan berbagai dampak negatif di antaranya adalah pertumbuhan, perkembangan dan kecerdasan anak terhambat serta anak akan lebih mudah terserang penyakit karena penurunan daya tahan tubuh ${ }^{15}$. Konsekuensi fungsional dari anemia gizi menyebabkan turunnya kualitas sumber daya manusia secara$^{7}$. Selain itu zat besi sangat berperan dalam metabolisme anergi, sistim oksidasi, perkembangan dan fungsi syaraf, koneksi sistim jaringan, sintesis hormon, dan aktivitas 
antioksidant. Lebih dari 80 persen dari besi sistemik berperan dalam transport oksigen (haemoglobin) atau disimpan dalam bentuk myoglobin untuk mendukung metabolisme sistemik. ${ }^{16}$

Masih tingginya angka defisiensi besi dapat menggambarkan rendahnya asupan zat besi makanan. Kondisi ini sangat mungkin terjadi akibat pola pemberian makanan, yaitu Makanan Pendamping ASI (MP-ASI) yang tidak tepat. Salah satu permasalahan pemberian makanan yang terjadi pada anak usia dini adalah rendahnya pemberian ASI Ekslusif dan pola MP-ASI yang tidak tepat. ${ }^{17}$ Hasil analisis asupan zat besi dari makanan pada penelitian ini didapatkan 45,5 persen anak baduta dengan kategori defisit dengan rata-rata asupan zat besi hanya 6,99 gram. Hasil penelitian Hidayati, $\mathrm{dkk}^{18}$ menganalisis asupan besi pada anak usia 1-3 tahun di Surakarta menunjukkan rata-rata asupan zat besi hanya $5.54 \mathrm{mg} / \mathrm{hari}$ atau 69.24 persen dari kecukuan gizi yang dianjurkan (KGA). Hayati19 menganalisis rata-rata asupan zat besi anak 0-23 bulan didapatkan rata-rata tingkat kecukupan zat besi dari asupan hanya 36,9 persen dari KGA. Keadaan ini menggambarkan masih rendahnya tingkat asupan zat besi pada anak baduta. Sementara zat besi merupakan salah satu unsur utama pembentuk Haemoglobin, kadar zat besi yang rendah dalam simpanan tubuh. Zat besi berfungsi dalam pembentukan sel darah merah, pengangkut $\mathrm{O}_{2}$ dan $\mathrm{CO}_{2}$, sebagian kecil $\mathrm{Fe}$ dalam tubuh terdapat dalam enzim jaringan yaitu sekitar 7,0 persen.

Hasil penelitian yang disajikan pada Tabel 2, menunjukkan penderita anemia lebih banyak didapatkan pada anak yang mengalami defisiensi besi, yaitu 72,8 persen menderita anemia, sedangkan pada anak yang tidak defisiensi besi anemia lebih kecil, yaitu 31,5 persen. Hasil uji statistik menunjukkan ada perbedaan yang signifikan antara defisiensi besi dengan anemia pada anak baduta $p<0,05$ dan anak yang mengalami defisiensi besi mempunyai risiko 5,8 kali lebih besar untuk menderita anemia dibandingkan dengan anak yang tidak defisiensi besi. Artinya anemia pada penelitian ini masih sebagian besar disebabkan oleh defisiensi besi, namun demikian juga anemia karena faktor lain juga tinggi yang dapat dilihat dari 31,5 persen sampel yang anemia tetapi tidak mengalami defisiensi besi.
Pada penelitian ini faktor yang dianalisis hanya status besi sebagai penyebab anemia sementara status gizi mikro lainnya seperti status folat, zinc dan vitamin B12 sampel tidak dianalisis, sehingga pada sebagian kasus yang didapat dimana sampel tidak defisiensi besi tetapi menderita anemia. Hasil ini sama dengan hasil penelitian yang dilakukan di Demak 2002 pada ibu hamil, menggunakan parameter transferin, yaitu serum transferrin receptor, hasilnya prevalensi Anemia Gizi besi (AGB) dari ibu hamil anemia yang sebelumnya ditentukan dengan $\mathrm{Hb}$ ternyata tidak setinggi yang diduga. Dari 59,3 persen kasus anemia dengan parameter $\mathrm{Hb}$ ternyata hanya 3,7 persen $\mathrm{yg}$ mengalami defisiensi besi murni, sedangkan 55,6 persen disebabkan defisiensi zat besi dan salah satu zat gizi mikro lainnya; zink, vitamin $\mathrm{A}$ atau vitamin B12. Lebih dari $1 / 3$ kasus $(37,0$ persen) defisiensi zat gizi mikro lain tanpa defisiensi zat besi dan 3,7 persen lainnya tidak mengalami deisiensi zat gizi mikro apapun. ${ }^{20}$

Anemia gizi pada bayi dan anak dapat disebabkan oleh asupan zat besi yang tidak cukup, penyerapan zat besi yang kurang, kebutuhan zat besi meningkat, dan kehilangan darah akibat infeksi. ${ }^{21}$ Hasil penelitian di Afrika dan Amerika Latin menemukan infeksi cacing gelang (urutan ketiga), setelah diare, TBC dan infeksi cacing tambang dan keempat cacing cambuk infeksi cacing (gelang dan cambuk, tambang) menyebabkan perdarahan yang menahun sehingga menyebabkan penurunan cadangan zat besi. Pada penelitian ini tidak dilakukan analisis serum transferrin receptor (STfR) untuk mengetahui apakah terjadi imflamasi akibat infeksi dan penyakit kronis karena ferritin sangat dipengaruhi oleh inflamasi. ${ }^{20}$

Selain itu tingginya angka penderita defisiensi besi pada anak baduta dapat disebsbkan oleh kualitas asupan zat besi dari makanan terutama MP-ASI yang rendah, salah satu indikator kualitas MPASI adalah densitas zat besi dalam MP-ASI. Makanan bayi dan anak harus memenuhi densitas yang baik. Untuk meningkatkan asupan Fe dan zink dari MP-ASI maka setiap 100 kkal MP-ASI harus mempunyai minimum density $\mathrm{Fe}$ adalah 4,5 pada usia 6-8 bulan, 3,0 pada usia 9-11 bulan dan 1,0 untuk usia $12-23$ bulan. ${ }^{22}$ 


\section{SIMPULAN DAN SARAN}

\section{Simpulan}

Ada perbedaan status besi (serum ferritin) dengan anemia pada anak usia 6-23 bulan. Anemia dan defisiensi besi pada anak baduta (6-23 bulan) sangat tinggi, sehingga anemia masih merupakan "severe public health problem" pada anak usia 6-23 bulan.

\section{Saran}

Perlu dilakukan program penanggulangan anemia pada anak baduta melihat angka prevalensi anemia defisiensi besi sangat tinggi dengan melihat penyebab anemia pada anak baduta, baik program intervensi besi melalui suplementasi dan peningkatan asupan besi dalam makanan terutama dari Makanan Pendamping Air Susu Ibu (MP-ASI) dan faktor penyebab lainnya antara lain asupan zat gizi makro, yaitu protein dan zat gizi mikro lainnya Vitamin A, B12, vitamin C dan zinc.

\section{UCAPAN TERIMAKASIH}

Terima kasih peneliti sampaikan kepada Kepala Dinas Kesehatan Aceh dan Kepala Dinas Kesehatan Kabupaten Aceh Besar, Kepala Puskesmas Kecamatan Lhoknga, Leupung dan Lhong yang telah memberikan izin pelaksanaan penelitian. Kepada seluruh kader Posyandu yang telah membantu lancarnya pelaksanaan penelitian ini, seluruh enumerator dari Program studi Diploma IV Gizi Poltekkes Kemenkes Aceh dan Petugas Pengambil sampel darah dari Laboratorium "P" Banda Aceh serta petugas Laboratorium Kimia Poltekkes Kemenkes Aceh yang telah membantu proses pengumpulan data di lapangan dan pemeriksaan di laboratorium. Kepada seluruh ibu anak baduta sampel penelitian ini yang telah bersedia menjadi sampel dan memberikan data pada penelitian ini.

\section{RUJUKAN}

1. Stoltzfus. RJ and Dreyfuss. ML.Guidelines for the Use of Iron Supplements to Prevent and Treat Iron Deficiency Anemia. Washington DC: INNAG, 2010.
2. Depkes RI. Laporan Survei Kesehatan Rumah Tangga (SKRT), Jakarta: Depkes RI, 2001.

3. Badan Penelitian dan Pengembangan Kesehatan Kemenkes RI. Laporan Riskesda 2013. Jakarta: Badan Litbangkes, 2013.

4. Kementerian Kesehatan RI. Laporan Riskesdas 2007. Jakarta: Badan Litbang Kesehatan, 2008.

5. Ahmad A, Suryana, Fitri Y. Hubungan ASI Ekslusif dan Anemia dengan Stunting pada anak usia 6-24 bulan di Kecamatan Darul Imarah Aceh Besar. Jurnal Nasuwakes.2011;4(1): 45-49.

6. Word Vision Indonesia Banda Aceh. Strategi Kesehatan 2008-2011 (saat ini dan kedepan). Makalah Diskusi Panel dan Workshop Anemia; Banda Aceh 23 September 2010.

7. World Health Organization. Assesing the Iron Status of Population. Geneva: WHO, 2004.

8. INACG (International Nutritional Anemia Consultative Group). Why Iron is Important and What to do about it: a new perspective. Report of the 2001. Hanoi: INACG, 2001

9. INACG (International Nutritional Anemia Consultative Group). Iron Deficiency in early life: Challenges and progress. Report of The 2004. Lima Peru: INACG, 2004.

10. World Health Organization. Iron deficiency anaemia: assessment, prevention and control. A guide for programme managers. Geneva: WHO, 2001.

11. Kraemer K, Zimmermann MB. Nutritional Anemia: Sight and life. Berlin: Press Germany, 2007.

12. Rohner F; Woodruff BA., Aaron, GJ, Yakes EA, Lebanan, May AO, Rayco-Solon P, Saniel, Ofelia P. Infant and young child feeding practices in urban Philippines and their associations with stunting, anemia, and deficiencies of iron and vitamin A. Food and Nutrition Bulletin.2013; 34(2): S17-S29.

13. Olney DK, Pollitt E, Kariger PK, Khlafan SS, Ali NS, Tielsch JM, et al. Young Zanzibari Childreen with Iron Deficiency, Iron Deficiency Anemia, Stunting, or Malaria Have Lower Motor Activity Scores and spend Less Time in Locomotion. The Journal of Nutrition. 2007;137(12): 27562762 
14. Hassan. K, Sullivan. KM, Yip. R, Woodruff. BA. Factors Associated with anemia in Refugee children. The Journal of Nutrition. 2007;137(10): 2194-2202

15. Sediaoetama AD. IImu Gizi untuk Mahasiswa dan Profesi (Jilid 1). Jakarta: Bhatara Karya Akbar, 2004.

16. Erdman. JW, Macdonald. IA, Zeisel. SH. Present Present Knowledge in Nutrition. 10th edition. S.I: ILSI, Willey Blackwell, 2012.

17. Departemen Kesehatan RI. Pedoman Umum Pemberian Makanan Pendamping Air Susu Ibu (MPASI). Jakarta: Direktorat Bina Gizi Masyarakat, 2000.

18. Hidayati.L, Hadi.H, Kumara.A. Kekurangan Energi dan Zat gizi Merupakan Faktor Risiko Kejadian Stunted Pada Anak Usia 13 Tahun yang tinggal di wilayah kumuh perkotaan Surakarta. Jurnal Kesehatan. 2010: 3(1): 89-104.
19. Hayati. AW. Faktor risiko stunting, pola konsumsi pangan, asupan energi dan zat gizi anak 0-23 bulan. Disertasi. IPB Bogor, Bogor: Institut Pertanian Bogor. 2013.

20. Depkes RI. Pedoman Penanggulangan Malaria di Indonesia, Jakarta: Depkes RI, 2000.

21. Djaja $S$ dan Soemantri $S$. Penyebab kematian Bayi Baru Lahir (Neonatal) dan Sistem Pelayanan Kesehatan yang Berkaitan di Indonesia. Buletin Penelitian Kesehatan. 2001;31(3); 155-165.

22. Dewey, KG dan Vitta. BS. Strategies for ensuring adequate nutrient intake for infants and young children during the period of complementary feeding. A\&T Technical Brief. 2013: 7(11): 24-32 